University of Nebraska - Lincoln

DigitalCommons@University of Nebraska - Lincoln

Mammalogy Papers: University of Nebraska

State Museum

Museum, University of Nebraska State

7-2009

\title{
Puncture-Resistance of Gloves for Handling Bats
}

Patricia W. Freeman

University of Nebraska-Lincoln, pfreeman1@unl.edu

Cliff A. Lemen

University of Nebraska-Lincoln, clemen2@unl.edu

Follow this and additional works at: https://digitalcommons.unl.edu/museummammalogy

Part of the Zoology Commons

Freeman, Patricia W. and Lemen, Cliff A., "Puncture-Resistance of Gloves for Handling Bats" (2009). Mammalogy Papers: University of Nebraska State Museum. 118.

https://digitalcommons.unl.edu/museummammalogy/118

This Article is brought to you for free and open access by the Museum, University of Nebraska State at DigitalCommons@University of Nebraska - Lincoln. It has been accepted for inclusion in Mammalogy Papers: University of Nebraska State Museum by an authorized administrator of DigitalCommons@University of Nebraska Lincoln. 


\title{
Puncture-Resistance of Gloves for Handling Bats
}

\author{
PATRICIA W. FREEMAN, ${ }^{1}$ School of Natural Resources and University of Nebraska State Museum, University of Nebraska-Lincoln, Lincoln, \\ NE 68583-0974, USA \\ CLIFF A. LEMEN, School of Natural Resources and University of Nebraska State Museum, University of Nebraska-Lincoln, Lincoln, \\ NE 68583-0974, USA
}

\begin{abstract}
We quantified protection given by a variety of gloves against bat bites by using steel indenters to simulate teeth and measuring forces needed to puncture the gloves. Level of protection given by gloves was compared to expected bite forces and tooth sharpness of bats. Cotton, plastic-coated synthetic fabric, and proprietary materials advertised as puncture- and cut-resistant were easy to penetrate compared to leather gloves. Split leather gives the highest level of protection, but with reduced dexterity. These are best for handling larger bats $(>40 \mathrm{~g})$ or if higher safety is preferred. Deerskin gives reasonable protection without much loss in dexterity for handling bats $<40 \mathrm{~g}$. (JOURNAL OF WILDLIFE MANAGEMENT 73(7):1251-1254; 2009)
\end{abstract}

DOI: $10.2193 / 2008-295$

KEY WORDS bats, bite force, canine teeth, gloves, leather, materials science, puncture-resistance.

Use of gloves is the first line of defense against bat bites and rabies, and there is value in knowing how tough different materials are for gloves. Our objective was to determine amount of protection against bat bites given by different types of gloves and to make recommendations for which gloves should be used when handling bats.

Handling bats safely, for both researcher and bat, is problematical. Bats submitted for testing to health departments often test positive for rabies with rates of 5-10\% being common; however, other studies quantifying rabies in natural populations of bats found infection rates at approximately 0.5\% (Constantine 1988, Hutson et al. 2001). Even the lower estimate means there is risk of encountering an infected bat, particularly if many bats are handled. Such risk would, in isolation, suggest use of heavy gloves to avoid puncture by bat teeth. However, bats are small with long, delicate bones in wings and legs, and handing with heavy gloves means less dexterity and longer handling times.

\section{METHODS}

We tested gloves made of leather from cow, deer, elk, goat, and pig. Thickness of leather varied considerably depending on the type of glove, which included baseball-batting, cardriving, work, and welding gauntlets. We also tested gloves made of cotton, plastic-coated synthetic fabric, and 2 proprietary gloves marketed as cut- and puncture-resistant.

Cowhide used to make gloves is normally split to reduce thickness. The top layer of the split contains the outer surface or fur surface that is recognized by its smooth finish. This top piece is often called top-grain leather. The bottom layer or flesh side of the split is called split grain or just split leather and has a rough, suede finish on both sides.

We tested 18 leather gloves: 5 top-grain cowhide work gloves, 3 split-cowhide work gloves, 2 pigskin work gloves, 4 goatskin ( 2 batting gloves and 2 lightweight driving gloves), 2 deerskin (lightweight driving gloves and work gloves), and 2 elk skin (thick work gloves and welding gauntlets). All

${ }^{1}$ E-mail: pfreeman1@unl.edu gloves we tested except the split cowhide were made of topgrain leather. We do not know whether the noncow leathers were split into layers.

Nonleather gloves we tested included 2 made of cotton, 2 made of plastic-coated synthetic fabric (Light Task and Nitri Task from North Safety Products, Cranston, RI), and 2 types of proprietary materials marketed as puncture- and cut-resistant (one layer of Aramid Plus fabric from TurtleSkin ${ }^{\circledR}$ [a subdivision of Warwick Mills, New Ipswich, $\mathrm{NH}$ ], and one layer of SuperFabric ${ }^{\circledR}$ from Hexarmor ${ }^{\circledR}$, Grand Rapids, MI). To test the effect of wear on TurtleSkin, we rubbed the fabric in our fingers for a few minutes. TurtleSkin is a stiff fabric to begin with, and although our manipulation of the fabric did soften the material somewhat, it still looked unworn with no fraying or obvious looseness to the weave.

We dulled and polished 3 stainless-steel sewing needles to span the range of tooth bluntness expected from bats. To get an index of bluntness of these needles, we drew the tips under magnification, and fitted a circle to each tip using the method described by Freeman (1992; Fig. 1). We defined bluntness as tip area $\left(\mathrm{A}=\pi \mathrm{r}^{2}\right.$ where $\mathrm{r}$ is the radius of curvature). Tip area for pin 1 was $0.024 \mathrm{~mm}^{2}$, for pin 2 was $0.056 \mathrm{~mm}^{2}$, and $0.264 \mathrm{~mm}^{2}$ for pin 3 . The same method to quantify bluntness was used on the upper canines of 13 species of bats (Freeman 1992).

We tested gloves by measuring the force needed to drive the steel indenters through the material using a uniaxial compression testing machine, the Inspec 2200 (Instron, Norwood, MA). The Inspec drove the indenters at $0.5 \mathrm{~mm} /$ second. Prior to penetration we placed the sample over a $1-\mathrm{cm}$ hole in a steel base and held it in place (Freeman and Lemen 2006). We chose 2 pieces of material from each pair of gloves. Each piece was penetrated 5 times by each of the 3 indenters.

Thickness of leather varied considerably among gloves and was an important factor in the protection a glove gave. However, because leather is compressible, simply using calipers to measure thickness is problematical because there is no way to control the amount of pressure applied when measuring thickness. As a result, we used the Inspec 2200 to 


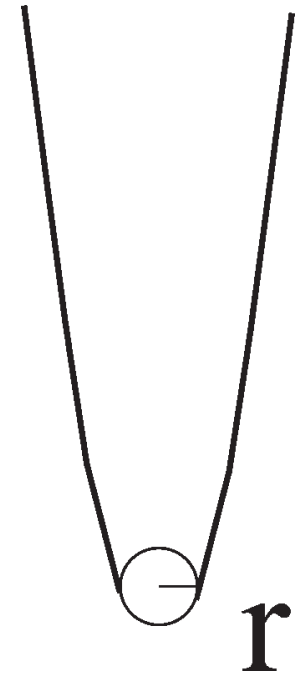

Figure 1. We quantified and reproduced the sharpness of the tip of an actual tooth or manufactured indenter by defining it as $\pi r^{2}$ where $r$ was the radius of a circle fitted to the tip of the indenter or tooth. The radius was short in a sharp tip and longer in a blunt tip.

measure leather thickness at the spots to be punctured. For each measurement we exerted a force of 5 Newtons $(\mathrm{N})$ on the leather with a circular, flat-tipped indenter with diameter of $1.0 \mathrm{~mm}$ against a flat, steel surface.

The resistance of different types of leather to puncture was analyzed using a generalized linear model analysis (SPSS for Windows, Rel. 15, 2007; SPSS, Chicago, IL) with type of leather as a class variable and thickness at point of penetration and bluntness of pin as covariates.

In the field we measured actual bite forces at the canines on 22 species of insectivorous, frugivorous, omnivorous, and nectarivorous bats (P. W. Freeman and C. A. Lemen, University of Nebraska-Lincoln, unpublished data) with a slim piezo-resistive sensor (Freeman and Lemen 2008). We ran a regression of $\log _{10}$-transformed body mass $(\mathrm{g})$ to maximum bite force $(\mathrm{N})$ using SPSS. We estimated bite forces for all species from this regression using body mass. Small bats were identified by body masses of $5-15 \mathrm{~g}$, midsized bats from $15 \mathrm{~g}$ to $40 \mathrm{~g}$, and large-sized $>40 \mathrm{~g}$. Our work in the field with live bats was reviewed and approved under protocol 06-01 003C from the Institutional Animal Care and Use Committee of the University of NebraskaLincoln.

\section{RESULTS}

We found that mid-sized bats (e.g., big brown bat [Eptesicus fuscus], at $15 \mathrm{~g}$, and hoary bat [Lasiurus cinereus], at $25 \mathrm{~g}$ ) had unworn canine teeth about equal to experimental pin 1 , our sharpest indenter. Large bats (e.g., greater spear-nosed bat [Phyllostomus hastatus], at $90 \mathrm{~g}$, and great fruit-eating bat [Artibeus lituratus], at $70 \mathrm{~g}$ ) had unworn teeth about equal to experimental pin 2 in sharpness. However, canines of many bats measured showed some wear and had blunter tips that would be between pins 2 and 3 in sharpness.

Average penetration force for pin 2 was $0.39 \mathrm{~N}$ for a cotton garden glove. A thicker cotton jersey glove averaged $0.60 \mathrm{~N}$. Of the 2 synthetic gloves with plastic coatings,
Light Task averaged $1.74 \mathrm{~N}$, and Nitri Task with its heavier coating averaged $8.4 \mathrm{~N}$. Of the 2 proprietary materials advertised as cut- and puncture-resistant, TurtleSkin $(\bar{x}=$ $25 \mathrm{~N})$ was far more resistant to puncture than Hexarmor $(\bar{x}$ $=5 \mathrm{~N}$ ) using pin 2 . However, much of the resistance to puncture of the TurtleSkin glove was dependent upon a light plastic coating on the fabric that held the threads together. The indenter had to force apart the threads or perhaps break threads to penetrate. After rubbing the fabric between our fingers to imitate wear, resistance to puncture by pin 2 dropped $50 \%$ to $12.15 \mathrm{~N}$.

Results of a generalized linear model analysis of gloves made of cow (both split and top grain), pig, elk, deer, and goat leather indicated thickness of hide, bluntness of pin, and type of leather were all highly significant with $P<$ 0.001 . The coefficient of determination, $R^{2}$, was 0.83 . By using estimated standard means generated in SPSS, we evaluated resistance to puncture of these leathers at standard values for covariates of hide thickness $(0.59 \mathrm{~mm})$ and pin bluntness $\left(0.11 \mathrm{~mm}^{2}\right)$. Force values in decreasing toughness were split cow, $62.5 \mathrm{~N}$; pig, $56.6 \mathrm{~N}$; deer, $41.1 \mathrm{~N}$; goat, 36.9 $\mathrm{N}$; top-grain cow, $30.5 \mathrm{~N}$; and elk, $23.9 \mathrm{~N}$. Pair-wise comparisons of leather types using the Bonferroni method showed elk skin and top grain had similar resistance to puncture but were easier to puncture $(P<0.001)$ than other leathers tested. Goat and deer leather were similar in strength but were weaker than split cowhide and pig $(P<$ $0.001)$, and finally, split leather and pigskin were similar in strength.

Variability in toughness or force of penetration occurred within a glove (Fig. 2). Some gloves had high variability. However, sometimes this variability was predictable based on differences in thickness within a pair of gloves. In one pair of thin deerskin driving gloves, where thickness of leather varied from $0.2 \mathrm{~mm}$ to $0.62 \mathrm{~mm}$, force of penetration for pin 2 ranged from $7 \mathrm{~N}$ to $32 \mathrm{~N}$. There were obvious thin areas in the leather, and they were weaker. Difference in leather thickness was more subtle in one pair of goatskin gloves $(0.32-0.40 \mathrm{~mm})$, yet range in force for pin 2 was high for these gloves as well $(12-29 \mathrm{~N})$.

Average force to puncture split leather (with $1 \mathrm{SD}$ ) for pins 1,2 , and 3 were $25.6 \pm 5.8 \mathrm{~N}, 38.5 \pm 10.2 \mathrm{~N}$, and $128.6 \pm 23.92 \mathrm{~N}$, respectively. Results for the other gloves in order of decreasing strength were deerskin work gloves $22.3 \pm 3.1 \mathrm{~N}, 29.58 \pm 1.44 \mathrm{~N}$, and $110.7 \pm 11.56 \mathrm{~N}$; topgrain cowhide work gloves $13.17 \pm 4.89 \mathrm{~N}, 18.66 \pm 7.14 \mathrm{~N}$, and $70.8 \pm 33.27 \mathrm{~N}$; and thin goatskin batter's gloves 11.4 $\pm 4.3 \mathrm{~N}, 15.4 \pm 5.4 \mathrm{~N}$, and $52.00 \pm 13.9 \mathrm{~N}$ (Fig. 3). On average the split-leather gloves were about 2.3 times more resistant to penetration than goatskin gloves.

We predicted bite force of bats using a regression model $\left[\log _{10}(\right.$ Bite Force $)=1.21 \times \log _{10}$ (Body Mass $)-0.7765$, $P=0.00001]$ for a series of bats for which we measured tooth sharpness (Fig. 3).

\section{DISCUSSION}

Our tests of cotton and plastic-coated fabric gloves proved that they offered little protection against bat bites. Even 


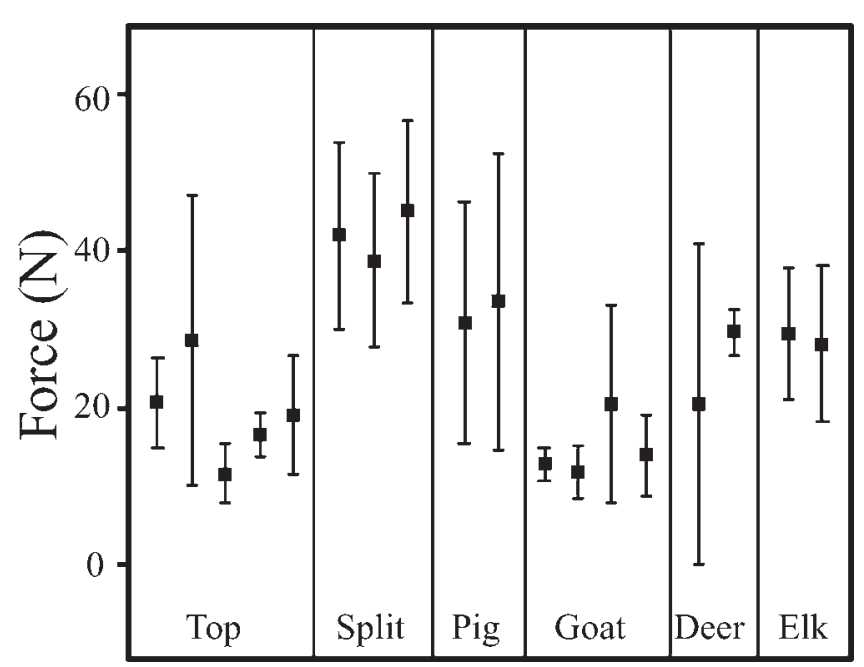

Figure 2. Mean force (Newtons $[\mathrm{N}]$ ) needed to penetrate pairs of leather gloves with pin 2, the moderately blunt indenter. Error bars are \pm 2 standard deviations for each pair of gloves. Gloves were grouped by material: top-grain cowhide, split cowhide, pigskin, goatskin, deerskin, and elk skin.

small bats bit with a force sufficient to penetrate fabric gloves. Plastic coating increased protection somewhat, but to achieve the level of protection afforded by even the thinnest leather glove would require a thick coating of plastic. The result would be stiff gloves with low dexterity. For these reasons we felt that cotton or plastic-coated fabric gloves were not suitable for handling bats. Further, TurtleSkin gloves were not considered for use with bats because of the rapid decrease in protection with wear, and the only average dexterity.

For similar thickness, split leather, deerskin, goatskin, and pigskin offered more protection than top-grain leather cowhide. Top-grain cowhide work gloves, one of the most common types available, were a poor choice because they offered less protection and no better dexterity than deerskin work gloves of similar thickness. Indeed we were surprised to find that deerskin, which was suppler than typical topgrain cowhide, was actually more resistant to puncture. However, puncture-resistance of a glove was dependent on both thickness and strength of leather. For the same thickness, goatskin was more resistant to puncturing than top-grain cowhide, but the goatskin gloves we tested were all thin $(\bar{x}=0.3 \mathrm{~mm})$, whereas top-grain work gloves were twice as thick $(\bar{x}=0.65 \mathrm{~mm})$. As a result, top-grain cowhide work gloves were slightly more puncture-resistant than thinner goatskin gloves.

Size of bat was a key factor in the selection of glove type. Larger bats have blunter teeth than smaller bats (Freeman and Weins 1997), but were more dangerous because their stronger jaws more than compensated for their blunter canine teeth. Although thin goatskin gloves are popular with bat biologists, our results indicated they gave insufficient protection against mid-sized bats with masses from $15 \mathrm{~g}$ to $40 \mathrm{~g}$ and estimated bite forces of $7 \mathrm{~N}$ to $17 \mathrm{~N}$. Pin 1 had sharpness similar to the unworn canines of bats in this size range. Pin 1 needed a force of only $11.4 \pm 4.3 \mathrm{~N}$ to

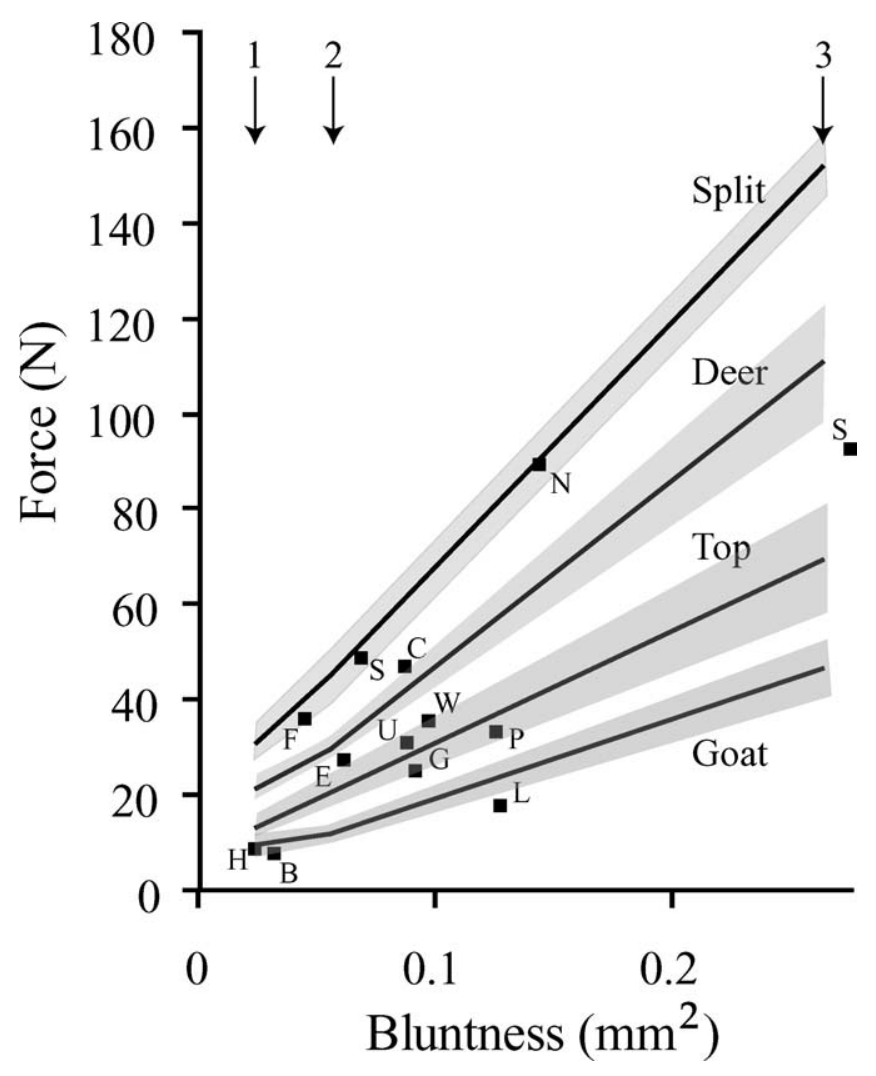

Figure 3. We studied the protection given by a variety of gloves against bat bites in 2007 and show the relationship between force of penetration and bluntness found in 4 pairs of gloves. Each line is formed by connecting mean force of penetration and bluntness for pin 1, pin 2, and pin 3 (bluntness of pins is shown by arrows at the top of the graph). The shaded areas around the lines represent \pm 1 standard deviation. Average leather thicknesses are split cowhide, $0.77 \mathrm{~mm}$; deerskin, $0.74 \mathrm{~mm}$; top-grain cowhide, $0.78 \mathrm{~mm}$; and goatskin, $0.24 \mathrm{~mm}$. Bluntness of canine tooth and predicted bite force for 13 species of bats (solid squares) are also plotted. When a bat's bite force and tooth bluntness plot above a glove's line, the bat is predicted to be able to penetrate that glove. Species used here from large to small are greater spear-nosed bat $(\mathrm{S})$, greater fruit-eating bat $(\mathrm{F})$, hoary bat $(\mathrm{H})$, and big brown bat (B). Other bats (Freeman 1992) are greater false vampire bat (Megaderma lyra $[G]$ ), Commerson's leaf-nosed bat (Hipposideros commersoni $[\mathrm{C}])$, Pratt's leaf-nosed bat (H. pratti $[\mathrm{P}])$, greater bulldog bat (Noctilio leporinus [U]), woolly false vampire bat (Chrotopterus auritus [W]), fringe-lipped bat (Trachops cirrhosus [L]), spectral bat (Vampyrum spectrum $[\mathrm{S}]$ ), greater naked bat (Cheiromeles torquatus $[\mathrm{N}]$ ), and greater bonneted bat (Eumops perotis [E]). Bats were selected to have relatively unworn canines, and bigger bats have blunter teeth.

penetrate goatskin. The protection of thin leather gloves against even larger bats $(40-90 \mathrm{~g}$, with bite forces from $17 \mathrm{~N}$ to $40 \mathrm{~N}$ ), was even less. Unworn canines of these bats were similar in sharpness to pin 2, which needed only a force 15.4 $\pm 5.4 \mathrm{~N}$ to penetrate goatskin. The toughest, most protective gloves we tested were split-leather work gloves, which offered about 2.3 times the protection of goatskin gloves. Based on our calculations, these gloves gave sufficient protection against mid-sized bats (penetration forces for pin 1 averaged $25.6 \pm 5.8 \mathrm{~N}$ ). However, the largest species, such as the greater spear-nosed bat at $90 \mathrm{~g}$, might penetrate even these sturdy gloves (penetration of pin 2 averaged $38.5 \pm 10.2 \mathrm{~N}$ of force).

In contrast to our experimental results, our field experience and those of colleagues who used split-leather work gloves 
found that large bats did not penetrate these gloves. Several factors might explain this discrepancy. In our lab study we assumed a bat bites with maximal force with one upper canine. When we measured bite force in the field, both upper canines were engaged in a symmetrical bite. Further, bites to gloves in the field often engage more than a single upper canine. If both upper canines are involved, the force at each canine is only one half our estimated bite force. Finally, tooth wear had a large impact on force of penetration. Whereas an unworn canine of a large bat can have sharpness similar to pin 2, routinely these bats had moderate wear that was closer to the sharpness of pin 3, our bluntest experimental pin. This increased bluntness from pin 2 to pin 3 means the force to penetrate split leather increased from $38.5 \mathrm{~N}$ to $128.6 \mathrm{~N}$.

Finally, we found that deerskin work gloves were supple and, subjectively, had better dexterity than split-leather gloves. This increase in dexterity came with protection that averaged about $82 \%$ of split-leather gloves. This was better than goatskin that averaged only $43 \%$ of the protection of split leather. When many bats must be handled quickly, dexterity was an important and necessary requirement for researchers. Deerskin gloves, particularly when handling only small to mid-sized bats, were good protection. If only a few bats were to be handled, loss of dexterity may not be as important because there was more time to remove bats. In such cases, and especially if larger species were being handled, split-leather gloves should be used.

Several colleagues used thin or even no gloves both to increase dexterity and to reduce the chance of harming bats. However, others who use split-leather gloves did not report harming bats. Perhaps with large samples of bats some difference might be found, but damage to bats by skilled biologists was low regardless of the gloves used. In our experience the problem of rough handling, or rushed handling of bats was a more important issue. Thus, proper training on methods of handling bats may be more critical than the type of gloves used.

Care must be used in selecting gloves. Inspection for thin areas or low-quality leather that would create weak spots was important. Split-leather gloves offered the best protection of gloves tested, but an individual pair of gloves might have a thin spot that would compromise their safety.

\section{Management Implications}

Glove recommendations are related to size and, therefore, bite force of bats being captured. Split-leather cowhide work gloves, the most puncture-resistant of the gloves we tested, are best for big bats approximately 40-100 g. Unfortunately these gloves have low dexterity. Deerskin work gloves are a good compromise of both puncture-resistance and dexterity and are excellent for handling small to mid-sized bats approximately 4-40 g. Thin goatskin gloves offer maximum dexterity, but can resist bites of only the smallest bats, approximately 5-15 g. Given the natural variation in leather and problems of wear, gloves are not absolute protection against bites of bats.

\section{Acknowledgments}

We especially thank colleagues who responded to our informal survey of their glove use with bats: R. M. R. Barclay, M. A. Bogan, W. Caire, J. R. Choate, J. Coleman, Keith Geluso, Ken Geluso, M. Herder, T. H. Kunz, R. A. Medellin, T. R. Mollhagen, D. J. Neubaum, S. C. Pedersen, P. A. Racey, J. J. Rasweiler, IV, D. Solick, and J. R. Winkleman. In addition Keith Geluso, Ken Geluso, and M. Harner were important for our success in the field. We are grateful to curators of collections at the University of Kansas and Field Museum of Natural History for specimens used in this study. Thanks also go to the University of Nebraska Agricultural Research Division, the School of Natural Resources, the University of Nebraska State Museum, and the University of Nebraska Research Council for support.

\section{LITERATURE CITED}

Constantine, D. G. 1988. Health precautions for bat researchers. Pages 491-528 in T. H. Kunz, editor. Ecological and behavioral methods for the study of bats. Smithsonian Press, Washington, D.C., USA.

Freeman, P. W. 1992. Canine teeth of bats (Microchiroptera): size, shape and role in crack propagation. Biological Journal of the Linnean Society 45:97-115.

Freeman, P. W., and C. A. Lemen. 2006. Puncturing ability of idealized canine teeth: edged and non-edged shanks. Journal of Zoology (London) 269:51-56.

Freeman, P. W., and C. A. Lemen. 2008. Measuring bite force in small mammals with a piezo-resistive sensor. Journal of Mammalogy 89:513517.

Freeman, P. W., and W. N. Weins. 1997. Puncturing ability of bat canine teeth: the tip. Pages 151-157 in T. L. Yates, W. L. Gannon, and D. E. Wilson, editors. Life among the muses: papers in honor of J. S. Findley. Museum of Southwestern Biology, Special Publication 3, Albuquerque, New Mexico, USA.

Hutson, A. M., S. P. Mickleburgh, and P. A. Racey. 2001. Chapter 3: microchiropteran bats. Pages $36-51$ in A. M. Hutson., S. P. Mickleburgh, and P. A. Racey, compilers. Microchiropteran bats: global status survey and conservation action Plan. International Union for the Conservation of Nature Publication (ISBN 2831705959, 9782831705958), Cambridge, United Kingdom.

Associate Editor: Green. 